\title{
OTONOMI DAERAH DAN PERGURUAN TINGGI
}

\author{
Oleh Shohibul Anshor Siregar
}

Harian Waspada menggelar sebuah diskusi serius tentang peran Perguruan Tinggi (PT) dalam mendorong otonomi daerah, dua pekan lalu. Dalam diskusi itu Harian Waspada menekankan pentingnya identifikasi gagasan genuine kampus yang sekiranya dapat diidentifikasi sebagai arah membangun Negara dari Sumatera Utara. Karena itulah kehadiran Rektor USU, Rektor Unimed dan Rektor UINSU dianggap sangat penting. Diskusi juga menerima pendapat dari tiga pembanding (Prof Dr H Syahrin Harahap, MA dari UINSU, Dr Warjio,MA dari USU dan penulis sendiri dari UMSU). Tulisan ini bermaksud mengelaborasi lebih luas peta pembicaraan dalam diskusi tersebut.

Salah satu masalah yang sangat perlu disadari ialah tentang konsepsi otonomi daerah. Menurut sejarahnya gagasan ini adalah sebuah produk politik yang sangat canggung yang sekaligus menunjukkan pengawetan dialog tak usai dalam kontroversi bentuk Negara, apakah unitaris atau federalis. Semua tahu belakangan gagasan yang berbenturan ini diselesaikan tanpa diskusi berimbang, karena hanya lebih mengamini hegemoni pusat yang terlihat dalam setiap produk undang-undang, terutama sejak reformasi. Wakil-wakil daerah yang diorbitkan ke pentas nasional sama sekali tak pernah faham masalah ini. Belakangan malah setiap gagasan yang mengarah kepada perujukan atas federalisme ditentang sangat keras. Ungkapan-ungkapan seperti "NKRI harga mati" adalah bentuk-bentuk komunukasi politik yang dipersiapkan untuk memojokkan gagasan yang menginterupsi hegemoni pusat.

Dalam filosofi yang melatari otonomi daerah terjejaki sangat jelas ambivalensi unitarisme dan federalisme. Jakarta mungkin selalu dibayang-bayangi trauma kondisi Indonesia saat diterapkannya model federalisme yang mencatatkan kadar kesetiaan yang rendah dari Negara-negara bagian (daerah) kepada pemerintahan pusat (Indonesia), ditambah lagi peristiwa-peristiwa perlawanan yang bahkan pernah melahirkan perang saudara yang kesemuanya dikategorikan sebagai gerakan separatisme. Tetapi akar masalah trauma itu sendiri perlu didudukkan.

Dengan mengugurkan sementara faktor pengaruh luar negeri terutama Amerika Serikat (misalnya dalam peristiwa PRRI/Permesta), otonomi daerah sebetulnya harus didudukkan kepada sumbernya yang original, yakni bunyi UUD 1945. Muhammad Ali Safa't, dosen 
Fakultas Hukum Universitas Brawijaya, Malang, dalam tulisannya berjudul "Konstitusionalitas Pengalihan Kewenangan Pengelolaan Pendidikan Menengah dari Kabupaten/Kota ke Provinsi”, yang disampaikan pada tanggal 17 Mei 2016 sebagai Keterangan Ahli pada Sidang Mahkamah Konstitusi Republik Indonesia (Perkara Nomor 30/PUU-XIV/2016 pengujian UU Nomor 23 Tahun 2014 terhadap UUD 1945) berpendapat bahwa secara keseluruhan UU Pemda lebih menekankan pada paradigma Negara kesatuan dengan logika bahwa kekuasaan pemerintahan ada pada pemerintah pusat. Urusan yang menjadi kewenangan daerah sebagai dasar pembentukan daerah otonom semata-mata adalah pemberian dari pemerintah pusat. Otonomi berasal dari sentralisasi. Konsekuensinya, apakah daerah diberi kewenangan atau tidak, atau urusan apa yang diberikan kepada daerah sepenuhnya merupakan kewenangan pemerintah pusat.

Muhammad Ali Safa'at menunjukkan beberapa bukti antara lain bahwa dalam penegasan kekuasaan Presiden dalam UU Pemda disebutkan bahwa walaupun di dalam pengertian umum pemerintahan daerah UU Pemda masih memuat prinsip otonomi yang seluas-luasnya, namun hal itu tidak disinggung lagi dalam pasal-pasal dan digantikan dengan ketentuan tentang Kekuasaan Pemerintahan yang menegaskan kekuasaan Presiden sebagai pemegang kekuasaan pemerintahan negara. Pasal 5 UU Nomor 23 Tahun 2014 menyatakan (1) Presiden Republik Indonesia memegang kekuasaan pemerintahan sesuai dengan Undang-Undang Dasar Negara Republik Indonesia Tahun 1945. (2) Kekuasaan Pemerintahan sebagaimana dimaksud pada ayat (1) diuraikan dalam berbagai Urusan Pemerintahan. (3) Dalam menyelenggarakan Urusan Pemerintahan sebagaimana dimaksud pada ayat (2), Presiden dibantu oleh menteri yang menyelenggarakan Urusan Pemerintahan tertentu. (4) Penyelenggaraan Urusan Pemerintahan sebagaimana dimaksud pada ayat (2) di Daerah dilaksanakan berdasarkan asas Desentralisasi, Dekonsentrasi, dan Tugas Pembantuan.

Niat besar dari penempatan ketentuan tersebut di atas di dalam UU Pemerintahan Daerah bermakna penegasan bahwa otonomi daerah yang dibentuk melalui desentralisasi hanyalah pemberian dari pemerintah pusat yang konsekuensinya dapat memusuhi substansi gagasan otonomi itu sendiri. Seberapa besar urusan yang diberikan melalui desentralisasi, dekonsentrasi, dan tugas pembantuan akhirnya tak lain kecuali sangat bergantung kepada keinginan pemerintah pusat semata.

Jika dibandingkan dengan Pasal 2 ayat (3) UU Nomor 32 Tahun 2004 terdapat perbedaan cukup besar karena penegasan bahwa pemerintah daerah menjalankan otonomi seluasluasnya. 
Artinya, pemerintahan daerah memiliki kewenangan atas semua urusan pemerintahan kecuali urusan pemerintahan yang menjadi urusan Pemerintah, dengan tujuan meningkatkan kesejahteraan masyarakat, pelayanan umum, dan daya saing daerah. Secara gradatif substansi otonomi daerah itu pun mengalami persempitan dari UU sebelumnya (UU No 22 Tahun 1999).

Pertanyaan para negarawan otomatis tertuju kepada bagaimana sesungguhnya konstruksi Negara Kesatuan dan Otonomi Daerah berdasarkan UUD 1945? Apakah daerah juga memiliki kewenangan konstitusional dalam berbagai bidang yang sangat penting untuk perwujudan peran daerah sebagai bagian dari kesatuan Indonesia? Semua itu harus dihadapkan kepada sebuah rumus bahwa sentralisasi itu sejatinya tidaklah boleh menghilangkan keberadaan otonomi daerah sebagai amanat konstitusi. Merujuk pada pembahasan BPUPKI yang menghasilkan rumusan Pasal 18 UUD 1945 yang menyatakan bahwa pembagian daerah Indonesia atas daerah besar dan kecil, dengan bentuk susunan pemerintahannya ditetapkan dengan Undang-Undang, dengan memandang dan mengingat dasar permusyawaratan dalam sistem pemerintahan Negara, dan hak-hak asal-usul dalam daerah-daerah yang bersifat istimewa.

Sesungguhnya dalam penjelasan Pasal 18 UUD 1945 (sebelum perubahan) keberadaan otonomi daerah dan daerah otonom tampak semakin dipertegas dengan narasi "oleh karena Negara Indonesia itu suatu eenheidsstaat, maka Indonesia tak akan mempunyai daerah di dalam lingkungannya yang bersifat staat juga. Daerah Indonesia akan dibagi dalam daerah propinsi dan daerah propinsi akan dibagi pula dalam daerah yang lebih kecil. Di daerahdaerah yang bersifat otonom (streek dan locale rechtsgemeenschappen) atau bersifat daerah administrasi belaka, semuanya menurut aturan yang akan ditetapkan dengan undang-undang. Di daerah-daerah yang bersifat otonom akan diadakan badan perwakilan daerah, oleh karena di daerah pun pemerintahan akan bersendi atas dasar permusyawaratan.

Otonomi daerah yang layak disebut berasa sentralisme difahami menjadi biang penyebab disparitas. Tetapi pemerintah pusat selalu berbahasa ganda, bahwa dalam bahasa politik selalu mengesankan keinginannya untuk menumbuhkan kemampuan daerah tetapi dalam kebijakan serta perundang-undangan justru malah membonsai daerah. Apa yang dapat dilakukan oleh daerah adalah sesuatu yang sepenuhnya tergantung kepada kecanggungan memahami otonomi daerah itu sebagai bagian integral dan senafas dengan bentuk Negara 
kesatuan yang dengan demikian otonomi daerah itu semsetinya adalah hak konstitusional ketimbang hak yang bersumber dari kebaikan pemerintah pusat.

Jika Tap MPR Nomor XV/MPR/1998 yang mengamanatkan penyelenggaraan otonomi daerah dengan memberikan kewenangan yang luas, nyata dan bertanggung jawab kepada daerah secara proporsional yang diwujudkan dengan pengaturan, pembagian dan pemanfaatan sumber daya nasional yang berkeadilan, serta perimbangan keuangan pusat dan daerah yang dahulu ditindaklanjuti dengan pembentukan UU Nomor 22 Tahun 1999 yang memberikan kewenangan sangat besar kepada daerah otonom, terutama daerah kabupaten dan kota yang dinyatakan sebagai tempat penyelenggaraan otonomi daerah secara utuh, maka kini semua itu menjadi sesuatu yang hayali belaka. Semua itu bertanggungjawab atas pengaweten kesenjangan mendasar saat ini. Dicurigai bahwa model otonomi inilah yang bertanggungjawab dalam pembonsaian daerah, termasuk dalam membonsai kapasitas fiscalnya (bandingkan data menyedihkan kapasitas fiscal daerah yang dimuat dalam Peraturan Menteri Keuangan Nomor 37 Tahun 2016).

Bagaimana dengan PT? Sebetulnya dengan pemnbahasan di atas sudah sangat terasa kesiasiaan membahas peran PT, baik negeri mau ;pun swasta. Begitu pun tidaklah sia-sia menelaah gendang dan tari yang selama kurang lebih satu dasawarsa ini dimainkan oleh PT. PT di Indonesia kini sedang digiring kepada rumus hegemoni skala baru sesuai dengan globalisasi. Tahun 2007, satu dasawarsa yang lalu, Menteri Pendidikan Nasional (Mendiknas) Prof Dr Bambang Sudibyo MBA menyatakan sedang menyiapkan 50 Perguruan Tinggi (PT) di Indonesia untuk beranjak menjadi world class university (universitas kelas dunia, WCU). Dari ke-50 PT yang dipersiapkan waktu itu, 27 adalah milik pemerintah (negeri) dan 23 lainnya milik swasta. Langkah yang dilakukan akan bertahap, dimulai dengan mendorong ke50 PT itu menjadi world class university untuk tingkat ASEAN terlebih dulu.

Waktu itu dinyatakan hanya satu PT di Indonesia yang sudah masuk WU, yakni Universitas Terbuka (UT). Tiga lainnya sedang dalam proses mendapatkan akreditasi internasional yakni UI, UGM, dan ITB. Sebagai perbandingan misalnya, dalam daftar Worlds Top Universities versi The Times Higher Education Supplement - QS World University Rankings, waktu itu UI masih berada pada peringkat ke 250, ITB pada peringkat 258, UGM pada peringkat 275 dan Unair pada peringkat 330. 
Dengan begitu tampak bahwa bagi Indonesia tantangan berat untuk mengadaptasi menjadi WCU begitu nyata, apalagi dibandingkan dengan kondisi yang beragam dari populasi PT di Indonesia yang saat itu memiliki 82 PT negeri dan 2.700 PT swasta. Memang sebagai salah satu variable penting yang dianggap terkait dengan peningkatan kelas itu (ini memang sangat debatable), saat itu hanya 7 dari PT negeri sudah menjadi PT BHMN (Badan Hukum Milik Negara), yakni UI, UGM, ITB, IPB, USU, UPI dan Unair.

Tidaklah sesuatu yang mengada-ada menunjukkan penonjolan fenomena komersialisasi PT dalam rancangan mengejar status WCU itu. Akan tak pernah kurang argumen dari para pembijaksana untuk menunjukkan masalahat menuju WCU ini, sebanding dengan argumen kemunculan petaka yang tak terhindari. Mengapa? Realitas WCU itu sendiri lebih merupakan model pendidikan tinggi ber paradigma neolib barat yang didesign untuk memuluskan agenda hegemoni barat abad ke 21 .

Dalam pemeriksaan berbagai literatur sebetulnya ditemukan semangat utama WCU adalah penjajahan model baru mengandalkan konsep Knowledge Based Economy (KBE) yang menempatkan ilmu sebagai salah satu faktor produksi. Ilmu dan riset beroleh posisi penting tak lain dari jasa kapitalisasi plus komersialisasi yang muaranya adalah hasrat ekonomi paling tradisional yakni growth (pertumbuhan). Menjadi masuk akan protes keras Revrisond Baswir (UGM) bahwa dengan konsekuensi biaya pendidikan tinggi yang makin mahal, diskriminasi, Krisis identitas, krisis pakar dan ahli, komersialisasi riset dan pembajakan intelektual, cengkraman asing yang kian menguat, akses terhadap hajat hidup yang kian sulit, kerusakan lingkungan yang kian parah, dan lain-lain, justru menunjukkan angan-angan mengejar WCU itu tak lain dari jebakan neoliberalisme yang mengancam sebuah Negara seperti Indonesia.

Bagaimana jika diserukan kepada para rektor "bergeraklah untuk menjawab kebutuhan dan pembebasan bangsamu sendiri, perhatikan teriakan Edward Said, Gayatri Spivak dan semua ahli post colonial?" 